\title{
A new nematode of the genus Rhabdochona (Rhabdochona) from Botia dario (ornamental fish) from Jiri River, Jiribam, Manipur, India \\ ${ }^{*}$ R.K. Sanachaoba Singh, Ch. Dheinabi Devi and R.K. Gambhir
}

Parasitology Section, Centre of Advanced Studies in Life Sciences, Manipur University, CANCHIPUR-795003, IMPHAL (MANIPUR) INDIA

${ }^{*}$ Corresponding Author Email : rksanasingh3009@gmail.com

\section{Received : 10.08.2020; Accepted : 22.09.2020}

\begin{abstract}
During a taxonomic study of parasites of freshwater fishes, three new gravid female nematodes of the genus Rhabdochona were recovered from the intestine of a freshwater fish, Botia dario caught from Jiri River. Detail study revealed the specimen as a medium-sized nematode, tapering at both ends with finely striated cuticle, 14 anterior teeth in the funnel-shaped prostome, vulva post-equatorially open, vagina muscular, posteriorly directed with an ovejector, eggs oval, thinshelled and embryonated, tail tip conoidly pointed. Thus, the present species is assigned to the genus Rhabdochona. Prevalence and intensity of infection is $20 \%(1 / 5)$ and $3(3 / 1)$ parasite per host, respectively. Comparing the relative characteristics of the two conspecies, the present species closely resembles Rhabdochona (Rhabdochona) acuminata. It differs in a few aspects such as the longer oesophagus, more anteriorly located excretory pore, longer vagina, thin-shelled eggs but smooth-shelled eggs in $R$. $(R)$ acuminata, conoidly pointed tail tip but bluntly ended in $R$. (R.) acuminata. Based on these distinguishing characters the present species is described as a new species giving the name Rhabdochona (Rhabdochona) jiribamensis n. sp.
\end{abstract}

Figurs : $02 \quad$ References : 14

Tables : 02

KEY WORDS : Botia dario, Jiri River, R. jiribamensis.

\section{Introduction}

Manipur is located in the extreme east zone of India; there is a greater chance of availability of fish fauna which occurs in varied fresh water habitats being influenced by Burmese fish fauna. Jiribam is located in the western most part of Manipur where it borders with the states of Assam. It is drained by Barak River, Jiri River and many small canals. Manipur is also one of the states having a high fish consumption rate. Fisheries and aquaculture hold an essential role in food security, nutrition and employment of a large number of people. Besides proper awareness for a hygienic way of fish consumption is highly important as fishes are subjected to many parasitic infections due to their diverse feeding habits and habitats. During the course of a taxonomic study on parasites of freshwater fishes, in monsoon, three gravid female nematode species were recovered from the intestine of a fish host species, Botia dario ${ }^{5}$ from Jiri river.
The detailed comparative morphological analysis of the present species with their congeners reveals that it is closely related to the genus Rhabdochona ${ }^{13}$.

Rhabdochona are widely distributed as intestinal parasites infecting freshwater fishes in all zoogeographical regions of the world 8,11 . The species of the genus Rhabdochona posses funnel shaped prostom supported by short longitudinal ridges projecting anteriorly as sharp teeth, long and narrow mesostom. There are records of 97 valid species of Rhabdochona. Although, taxonomic characters of some Rhabdochona ${ }^{9}$ species still remain inadequately described, therefore more studies are highly needed.

\section{Materials and Methods}

Fishes were collected from Jiri River, Jiribam during monsoon (May-August) of 2018. Fishes were anaesthetised and examined for the presence of parasites.

ACKNOWLEDGEMENTS : The authors are grateful to the Head of Department, Life Sciences, Manipur University, for providing laboratory and library facilities, Mr. Nikhil Das for helping to collect the host fishes. The authors are also indebted to colleagues and friends for their valuable support. 
TABLE-1: Comparison of Rhabdochona(Rhabdochona) jiribamensis $n$. sp. with its closely related species; dfae (distance from anterior end); dfpe (distance from posterior end); ABD (anal body diameter).

(Measurements are given in micrometer except when indicated)

\begin{tabular}{|c|c|c|c|c|}
\hline Characters & $\begin{array}{l}\text { Rhabdochona (R) } \\
\text { jiribamensis n. sp. }\end{array}$ & $\begin{array}{l}\text { Rhabdochona (R) } \\
\text { acuminata }^{6}\end{array}$ & $\begin{array}{l}\text { Rhabdochona (R) } \\
\text { californiensis }^{1}\end{array}$ & $\begin{array}{l}\text { Rhabdochona (R) } \\
\text { denudata }^{4}\end{array}$ \\
\hline Body length (mm) & $8.96-13.87$ & $7.45-16.55$ & $8.72-10.67$ & $12.02-15.50$ \\
\hline Body width (mm) & $0.13-0.18$ & $0.09-0.19$ & $0.18-0.2$ & $0.16-0.19$ \\
\hline Teeth & 14 & 14 & 14 & 14 \\
\hline $\begin{array}{l}\text { Vestibule including } \\
\text { prostom }\end{array}$ & $112.5-137.88$ & $100-192$ & $107-135$ & $105-123$ \\
\hline $\begin{array}{l}\text { Muscular oesophagus } \\
(\mathrm{mm})\end{array}$ & $0.45-0.49 \times 0.02-0.03$ & $0.22-0.44$ & $0.33-0.49$ & $0.43-0.46 \times 0.03$ \\
\hline $\begin{array}{l}\text { Glandular oesophagus } \\
(\mathrm{mm})\end{array}$ & $2.45-3.99 \times 0.02-0.06$ & $1.05-1.91$ & $1.85-2.04$ & $4.45-5.39 \times 0.09-0.12$ \\
\hline $\begin{array}{l}\text { Whole length of } \\
\text { oesophagus }(\mathrm{mm})\end{array}$ & $2.90-4.49$ & $1.27-2.1$ & $2.21-2.86$ & $4.88-5.85$ \\
\hline Nerve ring (dfae) & $127-157$ & $127-228$ & $185-220$ & $189-207$ \\
\hline Excretory pore (dfae) & $160-252$ & $172-400$ & $310-380$ & $341-448$ \\
\hline $\begin{array}{l}\text { Deirids (dfae) } \\
\text { (bifurcated) }\end{array}$ & 65 (simple) & 41-63 (simple) & 53-86 (bifurcated) & $108-117$ \\
\hline Vulva (dfae) (mm) & $5.11-7.53(54-57 \%)$ & 3.35-7.7(dfpe) & $\begin{array}{l}4.26-5.68 \\
(48.8-53.2 \%)\end{array}$ & $\begin{array}{l}7.97-9.30 \\
\text { (dfpe: } 60-66 \% \text { ) }\end{array}$ \\
\hline Vagina & $367-662 \times 57.45-61.28$ & $219-377$ & $260-330$ & Not reported \\
\hline Uterus & Amphidelphic & Amphidelphic & Amphidelphic & Not reported \\
\hline Eggs & $\begin{array}{l}\text { 12-24x6-16 } \\
\text { (thin-shelled) }\end{array}$ & $\begin{array}{l}\text { 24-31x15-18 } \\
\text { (smooth-shelled) }\end{array}$ & $\begin{array}{l}31-37 \times 18-20 \\
\text { (thin smooth) }\end{array}$ & $\begin{array}{l}36-39 \times 24 \\
\text { (flock like coating) }\end{array}$ \\
\hline Tail (dfpe) & $\begin{array}{l}191-271 \text { (conoidly } \\
\text { pointed tip) }\end{array}$ & $\begin{array}{l}\text { 176-249 (conical } \\
\text { with bluntly ended } \\
\text { tip) }\end{array}$ & $\begin{array}{l}320-410 \text { (elongated } \\
\text { with a spicate } \\
\text { mucro) }\end{array}$ & $\begin{array}{l}\text { 165-171(conical } \\
\text { with spike) }\end{array}$ \\
\hline $\mathrm{ABD}$ & $48-57$ & Not reported & Not reported & Not reported \\
\hline Phasmids & Present & Present & Present & Not reported \\
\hline
\end{tabular}


The recovered parasites (three gravid females) were washed in normal saline solution $(0.7 \%)$. The specimens were fixed in A.F.A. (Alcohol Formalin Acetate) and dehydrated in G.A. (Glycerine Alcohol). The prepared permanent slides were examined under a light Olympus binocular microscope $(\mathrm{CH} 2 \mathrm{O})$ and photomicrographs were taken by Nikon Stereozoom-microscope (SMZ1270). Diagrams were drawn with the help of Camera Lucida and measurements of holotype and paratype specimens were taken by using Ocular micrometer. Measurements are given in micrometer $(\mu \mathrm{m})$ except when indicated.

\section{Observation:}

Rhabdochona (Rhabdochona) jiribamensis n. sp. Fig. 1(A-G), Fig. 2 (A-G)

\section{Female:}

Body medium-sized (8.96-13.87 x 0.13-0.18) $\mathrm{mm}$, tapering at both ends, cuticle finely striated, mouth tetragonally opens with two pairs of cephalic papillae, a pair of lateral amphid present near the mouth, 14 anteriorly directed teeth (8 lateral+3dorsal+3ventral) of the length 9.06-10.57 are present in the funnel-shaped prostome (19-26 x 15), vestibule straight (112.5-137.88), muscular oesophagus (457-497 x 26.25-33), glandular oesophagus (2.45-3.99 $\times 0.02-0.06) \mathrm{mm}$, the whole length of the oesophagus (2.90-4.49) mm. Deirids, nerve ring (26-34x 26-38) \& excretory located at $65,127-157,160-252$ respectively from anterior end. Excretory vesicle (95.75141.71), Vulva (5.11-7.53) post-equatorially open at 54$57 \%$ of the body length, vagina posteriorly directed with an ovejector \& has 3 portions: muscular vagina, muscular sphincter, and tromp. Uterus amphidelphic, ovary diovarial, the anterior ovary reaches near the oesophago-intestinal junction then reflexed downwards and posterior ovary extends near the rectum and then reflexed upwards. Eggs (12-24 x 6-16) oval, thin-shelled \& embryonated, tail (191$271 \times 48-57$ ) with conoidly pointed tip, phasmids present near the tail tip.

Male: Not found.

\section{Taxonomic summary:}

Type host: Botia dario Hamilton, 1822 (Botidae) Local name: Sarengkhoibi.

Site of infection: Intestine

Type locality: Jiri River, Jiribam $\left(24^{\circ} 79^{2}\right.$ North Latitude, $93^{\circ} 942$ East longitude), Manipur ( $23^{\circ} 50^{2}$ North to $25^{\circ} 412$ North Latitude, $93^{\circ} 00^{2}$ East to $94^{\circ} 452$ East Longitude), India.

Prevalence \& Intensity of infection: $20 \%(1 / 5)$ and 3(3/1) parasite per host, respectively.

Deposition of Specimens: Holotype and paratype specimens were deposited to the museum of Parasitology Section, Centre of Advanced Studies in Life Sciences, Manipur University, Canchipur-795003, Imphal, Manipur (India).

Etymology: The new species is named after it's locality of recovery- Jiribam, Manipur.

Ethical approval: All the procedures performed in research studies using fishes were in accordance with the ethical standards of the Institutional Animal Ethics Committee of Manipur University (M.U/D.Sc./ETHICS-7/ 09).

\section{Results}

A detail morphological observation of the 3 (three) gravid female enables for the identification of Rhabdochona (Rhabdochona) jiribamensis n. sp.

TABLE-2: Comparison of Rhabdochona (Rhabdochona) jiribamensis n. sp. with its closest species $R$.(R.) acuminata ${ }^{6}$, ABD (anal body diameter).

\begin{tabular}{l|l|l}
\hline Characters & Rhabdochona (R.) acuminata $^{6}$ & Rhabdochona (R) jiribamensis $\boldsymbol{n} . \mathbf{s p .}$ \\
\hline Oesophagus & Shorter in length & Longer in length \\
\hline Excretory pore & More posteriorly located & More anteriorly located \\
\hline Vagina & Posteriorly directed, shorter in length & Posteriorly directed, longer in length \\
\hline Eggs & Smooth-shelled & Thin-shelled \\
\hline Tail tip & Conical with bluntly ended & Conoidly pointed \\
\hline ABD & Not reported & $48-57 \mu \mathrm{m}$ \\
\hline
\end{tabular}



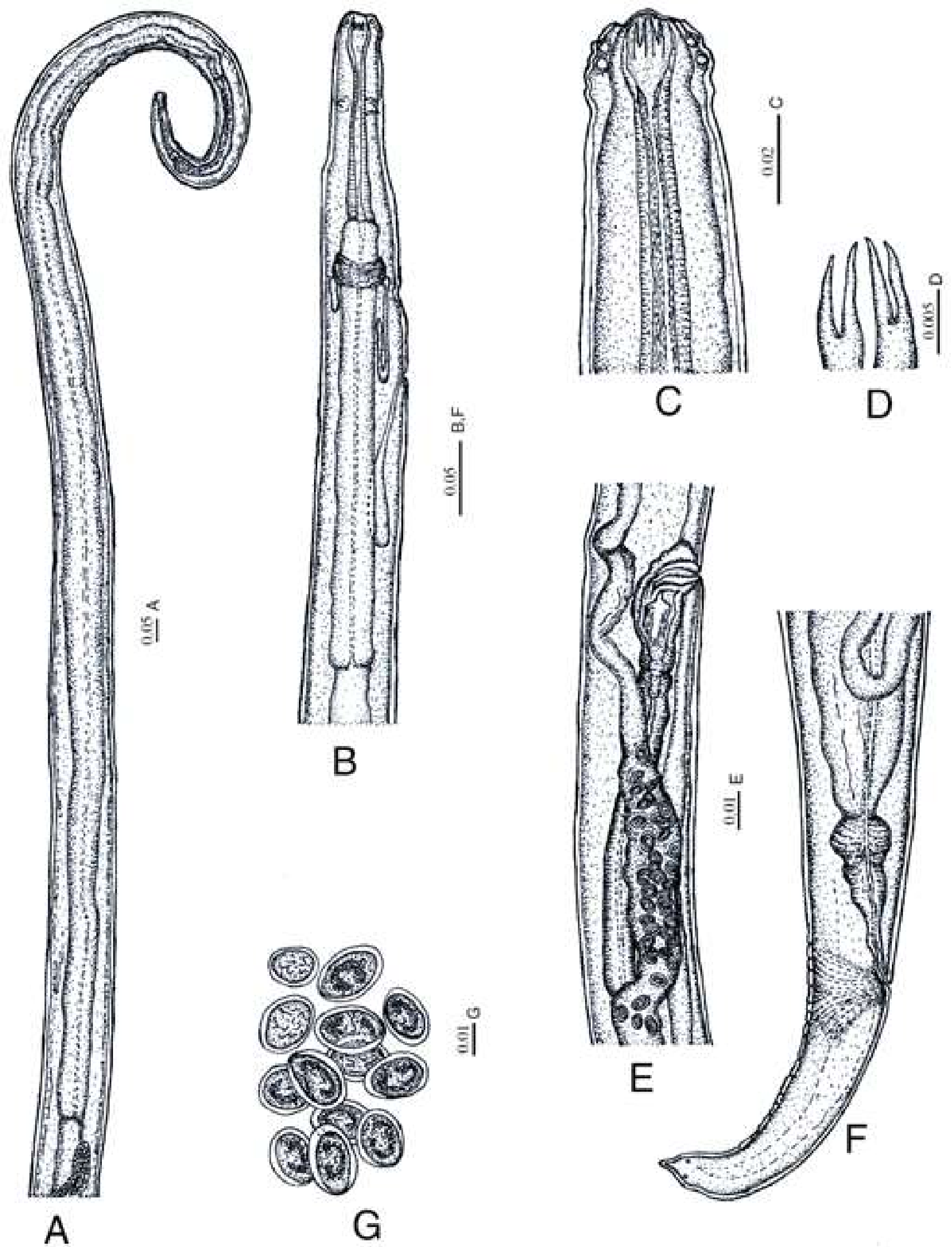

Fig. 1 (A-G) : Rhabdochona (Rhabdochona) jiribamensis n.sp. Female. (Scale bars in milimiters) Anterior end, lateral view, B) Anterior end, dorsoventral view, C) Anterior extremity, enlarge lateral view, D) Teeth, E) Vulvar region, lateral view, F) Posterior end, lateral view and G) Embryonated eggs (enlarged view) 


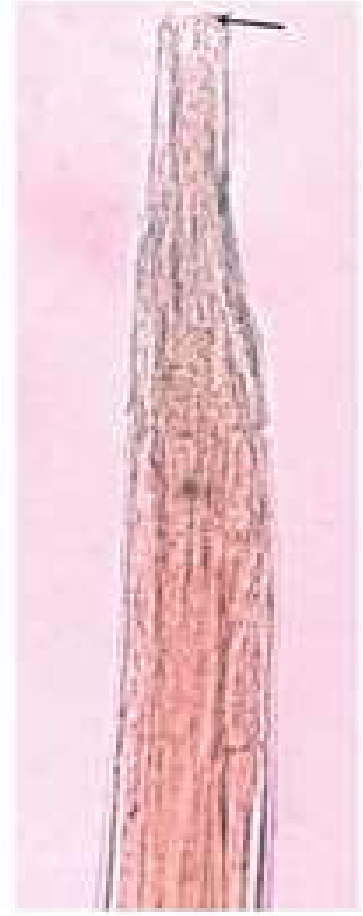

A

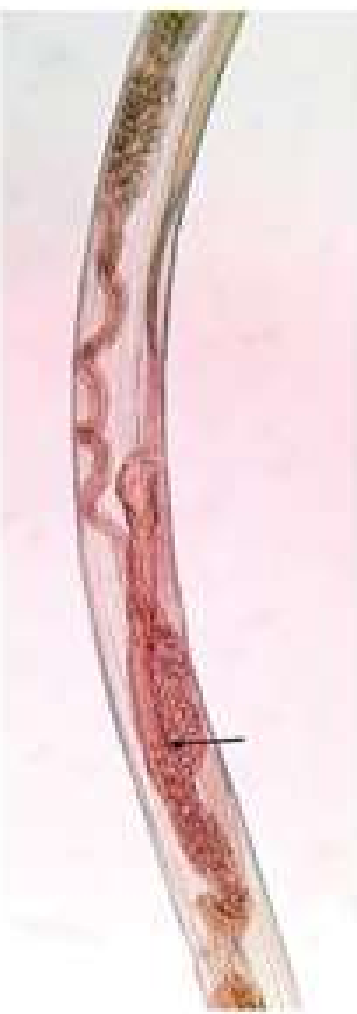

$\mathrm{E}$

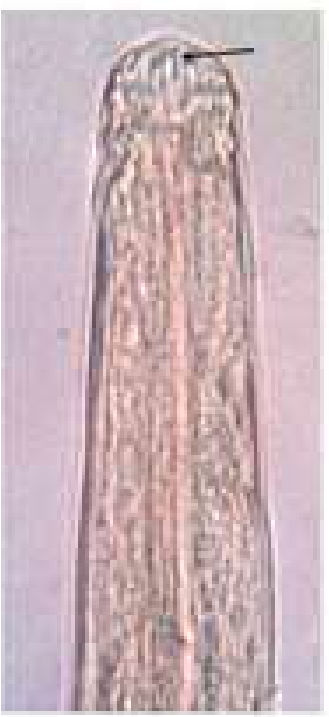

B

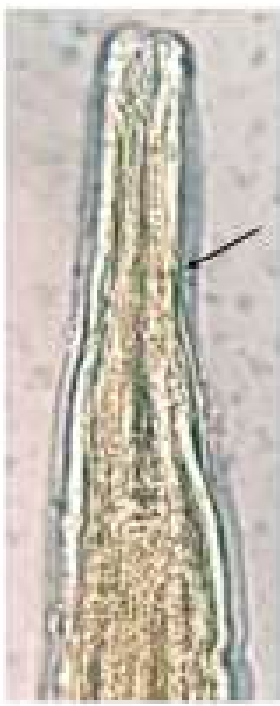

C

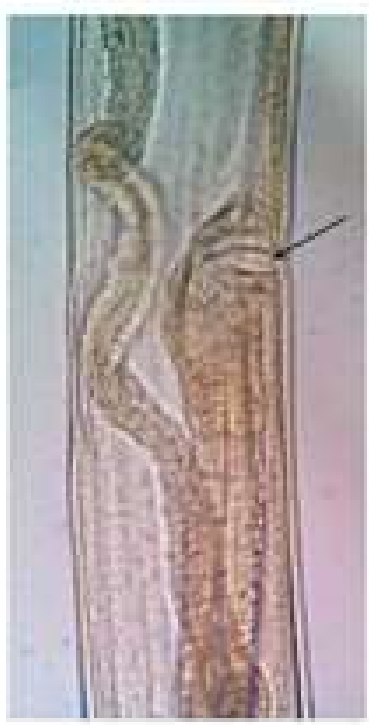

D

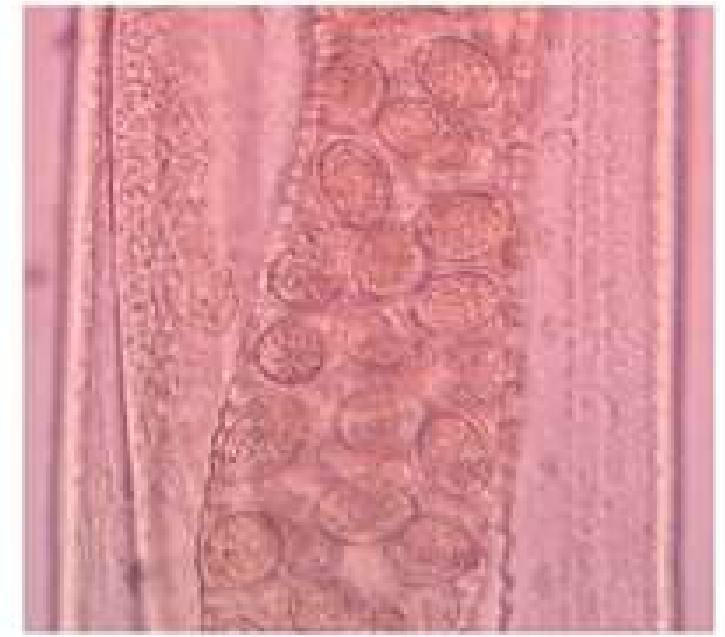

F

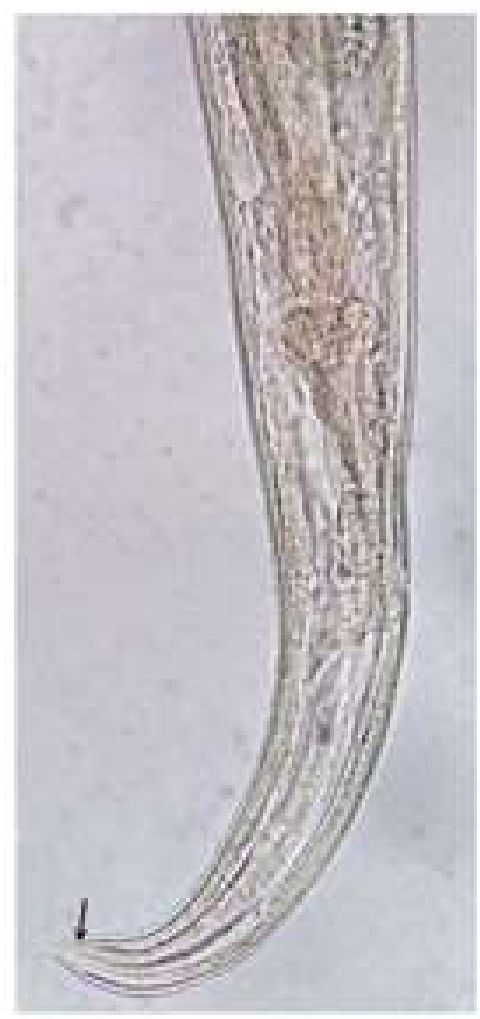

G

Fig. 2 (A-G) : Rhabdochona (Rhabdochona) jiribamensis n.sp. Female. A) Anterior region showing amphids, excretory pore, and nerve ring (dorso-ventral view), B) Anterior extremity showing teeth (enlarge lateral view), C) Anterior region showing deirids (dorso-ventral view), D) Mid-region showing vulva and vagina (lateral view), E) Mid-region showing bifurcation of uterus (lateral view), F) Mid- region showing eggs (lateral enlarged view) and G) Posterior end showing anal opening and phasmids (lateral view) 


\section{Discussion}

Rhabdochonid nematodes are recurrent parasites of fishes. The prostomial structure is one of the defining characters of Rhabdochonids ${ }^{2,10}$. Among the genera of Rhabdochonidae $^{2}$, only three genera Beaninema ${ }^{2}$, Fellicola ${ }^{12}$ and Rhabdochona ${ }^{13}$ possess an expanded anterior vestibular end that forms a funnel or barrel-shaped prostom and a posterior narrow tubular part forms mesotom. Rhabdochona differs from the rest genera in having short longitudinal ridges projecting anteriorly as sharp regular anterior teeth in the prostom.

Based on the morphology, eggs were classified ${ }^{14}$ the genus Rhabdchona into two subgenera Rhabdochona (eggs devoid of filaments), \& Filochona (filamented eggs). Later, based on the type of egg Moravec ${ }^{7}$ divided the genus into three subgenera Rhabdochona, Filochona, \& Globochona (eggs with special swellings). Further ${ }^{8}$ the only egg character is not sufficient to divide the genus into three subgenera and other characters such as number and arrangements of teeth in the prostom, presence of cervical alae, shape of the female tail tip \& shape of deirids must be included.

Numbers of subgenera were raised into 4 (four) such as Rhabdochona ${ }^{13}$ (with 10-14 or 16 anterior teeth, tail tip conical in female, ending in sharp cuticular spike or rounded, eggs with a smooth surface or with very fine irregular gelatinous flocks, filaments or special polar swellings), Globochona ${ }^{7}$ (with 8 or 12 anterior teeth, the tail tip of the female widely rounded with numerous spins, mucronate points or tooth-like processes, eggs smooth or with lateral globules or swellings), Globochonoides ${ }^{8}$ (8 anterior teeth, the tail tip of the female with a crown of a minute tooth-like processes, the tail tip of male rounded and eggs smooth), \& Sinonema ${ }^{8}$ (20-22 anterior teeth, the tail tip of female rounded).

But later ${ }^{3}$ were recognized only 3 (three) subgenera Rhabdochona (Rhabdochona) (eggs smooth or within ill-defined gelatinous covering), Rhabdochona (Filochona) ${ }^{14}$ (filamented eggs), and Rhabdochona (Globochona) ${ }^{7}$ (eggs with special hemispherical floats). From the overall studies the classification is followed in the present study which was widely accepted by many authors. The present species possess 14 anterior teeth in the prostom, a pair of simple deirid, conoidly pointed tail tip, and eggs with a smooth surface and nonfilamented. Thus, it is assigned to the subgenus

\section{Rhabdochona (Rhabdochona).}

The present species comes closer to species Rhabdochona (Rhabdochona) acuminata ${ }^{6}$, Rhabdochona (Rhabdochona) californiensis ${ }^{1}$ and Rhabdochona (Rhabdochona) denudata ${ }^{4}$ in many aspects such as in having 14 anterior teeth in the prostom, smooth eggshell without filaments, conical tail shape (Table-1).

Although Rhabdochona (Rhabdochona) californiensis differs from the present species in having shorter oesophagus (2.21-2.86) mm, bifurcated deirids, more posteriorly located excretory pore (310-380), more anteriorly open vulva (48.8-53.2\%), shorter vagina (260$330)$, more elongated tail (320-410) with a spicate mucro. Moreover, Rhabdochona (Rhabdochona) denudata ${ }^{4}$ differs from the present species in having longer oesophagus (4.88-5.85) $\mathrm{mm}$, bifurcated small deirids, more posteriorly located excretory pore (341-448), more posteriorly open vulva $(60-66 \%)$, smooth, larvated with flock like coating eggs, shorter tail (165-171) with a cuticular spike at the tip of the tail.

Considering the relative characteristics of the 3 (three) conspecies as shown in Table No.1, the present species is more closely related to Rhabdochona (Rhabdochona) acuminata ${ }^{6}$, in having both 14 anterior teeth, stylet like simple deirids, post-equatorially open vulva, non-filamented, oval with embryonated eggs, posteriorly directed vagina, amphidelphic uterus, diovarial ovary, the anterior ovary reaches near the oeso-phagointestinal junction then reflexed downwards and posterior ovary extends near the rectum then reflexed upwards, and in having a conical tail. In spite of many similarities, Rhabdochona (Rhabdochona) acuminata differs from the present species in many aspects (Table No.2) such as shorter oesophagus (1.05-1.91 versus $2.90-4.49) \mathrm{mm}$, more posteriorly located excretory pore (172-400 versus 160-252) mm, shorter vagina (219-377 versus $367-662$ ) $\mathrm{mm}$, smooth-shelled eggs versus thin-shelled eggs, conical tail with bluntly ended tip (176-249) versus conical tail with conoidly pointed tip (191-271). Based on these diagnostic morphometric differences from Rhabdochona (Rhabdochona) acuminata the present species could allow to erect as a new species and accommodated under Rhabdochona and assigned as a new species of Rhabdochona (Rhabdochona) giving the name as Rhabdochona (Rhabdochona) jiribamensis n. sp. (taking the name from Jiri river, Jiribam, the place of collection).

\section{References}

1. Armand R. Maggenti, Fawzia Abdel-Rahman, I. Cid Del Prado Vera. New Species of Rhabdochona Railliet, 1916 (Nemata: Rhabdochonidae) from Rainbow Trout in California Streams. J. Nematol. 1992; 24(3): 379-390.

2. Caspeta-Mandujano JM, Moravec F, Salgado-Maldonado G. Two new species of Rhabdochonids (Nematoda: 
Rhabdochonidae) from freshwater fishes in Mexico, with a description of a new genus. J. Parasitol. 2001; 87(1): 139-143.

3. Chabaud AG, Krishnasamy M. Noveaux nematodes ugenre Trichospirura Smith et Chitwood, 1967 en Malaysia. Remarques sur l'evolution de la famille des Rhabdochonidae. Ann. Parasitol. Hum. Comp. 1975; 50: 813-820.

4. Dujardin F. Histoire naturelle des Helminthes ou Vers intestinaux. Paris. sevangi. Sevanskaia ozernaia stantsiia Trudy. 1845; 4: 113-11.

5. Hamilton F. An account of the fishes found in the river Ganges and its branches, Edinburgh \& London, Fishes Ganges. 1822; 1-405.

6. Molin R. Una monografia del genere Spiroptera. Anzeigen der Akademie der Wissenschften, Wien Mathematischnaturwissenschaftliche. 1860; 38: 911-1005.

7. Moravec F. General characterization of the nematode genus Rhabdochona with a revision of the South American species. Vestnik Ceskoslovenke Spolecnosti Zoologicke. 1972a; 36: 29-46.

8. Moravec F. Reconstruction of the nematode genus Rhabdochona Railliet, 1916, with a review of the species parasitic in fishes of Europe and Asia. Studie CSVAV, Academia, Prague. 1975; 8: 104.

9. Moravec F, Kamchoo K. Description of Rhabdochona (Globochona) rasborae sp. n. (Nematoda: Rhabdochonidae) from the freshwater cyprinid fish Rasbora Paviana Tirant in Southern Thailand. Folia Parasitol. 2012; 59: 209215.

10. Moravec F, Maldonado GS, Carranza GC. New observations on Vasorhabdochona cablei (Nematoda:Rhabdochonidae) with remarks to the family Rhabdochonidae. Helminthologia. 2001; 38: 231-235.

11. Moravec F, Otero SC. Rhabdochona cubensis $s p$. $n$. (Nematoda: Rhabdochonidae) from the freswater fish Ganbasis punctata from Cuba. Helminthologia. 1987; 24: 103-110.

12. Peter AJ, Kale M. Fellicola longispiculus gen. new, sp. new. (Nematoda: Rhabdochonidae) from the gall bladder of the marine fish Coryphaenoides rupestris. Ann Parasitol Hum Comp. 1993; 68: 226-228.

13. Railliet A. La Famille des Thelaziidae. J. Parasitol. 1916; 2: 99-105.

14. Saidov Yu S. Revision of the family Rhabdochonidae Skrjabin, 1946 and the subfamily Cyclozoninae Sobolev, 1949, Sb. Rabory po gelmintologii Letiyu Akad. K. I. Skrajabina, Moscow. 1953; 75: 622-635. 